PhD Tihomir Jovanovski ${ }^{1}$

UDK 336.7:65.015.2

M.sci Mehmed Muric ${ }^{2}$

\title{
THE PHENOMENON OF LAG IN APPLICATION OF THE MEASURES OF MONETARY POLICY
}

\begin{abstract}
This paper discusses the theoretical aspect of the phenomenon of lag in the application of the measures of monetary policy. Monetary and fiscal policy faces the phenomenon of lag. One of the controversial and pressing questions of monetary policy is the nature and length of lag between the application of the measures of monetary policy and the effects on macroeconomic aggregates. While the monetary strategy points to several possible reasons for the lag, there is no general agreement on the length of the lag. The study of the phenomenon of lag imposes two questions: what does the lag of the application of monetary processes and policy imply and why are the asset holders not capable of immediately adjusting their portfolios at the time of disbalance? There are two categories of lag known in economic literature: the inside lag (which encompasses the recognition of the problem and the implementation of measures) and the outside lag (which encompasses the reaction of macroeconomic aggregates to the applied measures of monetary policy). The paper descriptively notes the different identifications of time lag and provides schematic representations of the effects of the observed phenomenon.
\end{abstract}

Key words: Monetary Policy, measures of monetary policy, time lag, problems of lag, consequences.

\section{INTRODUCTION}

The application of monetary politics and achieving the goals of monetary politics would be significantly facilitated if complete information about the effects of transitional mechanisms of monetary processes, as well as the actual relations between the instruments of monetary policies, financial and real variables existed. In such a case, the only thing left to the bearers of monetary policy to do is to fulfill the task at hand to the best of their capabilities, in respect to the handling of available instruments of monetary regulation in a way that results in known and wanted effects on the level and extent of change of final goals of monetary policies.

Within the process of formulation and application, monetary policy is marked by a far greater lack of information than most of the other economic policies. When discussing other economic policies, such as fiscal or foreign currency policies, it is possible to appropriately evaluate the situation and the effect of the changes brought on by one of the instruments of monetary policies on the variables of the ultimate macroeconomic goals.

As far as monetary policy is concerned, what remains unknown are the full effects of the change in the reference interest rate of the central bank or the change in reserve

\footnotetext{
European Center for Peace and Development (ECPD) - University for Peace established by United Nations.

${ }^{2}$ PhD student. Societe Generale Bank Serbia, mesamuric@gmail.com
} 
requirements with respect to inflation, employment or any other ultimate outcome variable of that policy, or even when that effect (i.e. with what time span) will be visible. The reason for this can be found in the fact that there is no complete information concerning the relations between the monetary sector of one economy and its real sector. The empirical experiences of the transfer of monetary impulses onto real variables and the feedback of the effects from the real towards the monetary sector of economy are still unsatisfactory [Živković \& Kožetinac, 2008, 291].

Monetary and fiscal policies face the phenomenon of lag. One of the controversial and pressing questions of monetary policy is the nature and length of lag between the application of the measures of monetary policy and the effects on macroeconomic aggregates. While the monetary strategy points to several possible reasons for the lag, there is no general agreement on the length of the lag [Cagan \& Gandolfi, 1969, 277].

The goal of this paper is to explain the phenomenon of lag in application of the measures of monetary policies from a theoretical aspect.

\section{THE PHENOMENON OF LAG}

The theoretical and empirical research into lag of the effects of monetary policies, as well as the phenomenon of lag itself, is needed because these measures are not visible immediately and fully, but after some time and appear inconsistently.

Essentially, there is no single occurrence which could be referred to as lag of the effects of monetary policies. If we presume that the effect of a single momentary monetary change to national income could be fully isolated, it would doubtlessly be seen that the effect immediately starts rising to its high point and then gradually decreases and does not stop for a certain period of time. Thus, the term of distributed temporal lag can be discussed. When we talk about a specific kind of lag, we usually refer to something as the average interval between the application and effect of a certain measure [Friedman, 1973, 262].

The application of monetary policy, but also macroeconomic policies in whole, is complicated by the presence of lag in the ultimate application of undertaken measures; the lag between the action of the policy and its effects on macro aggregates (production, employment, income, etc.); the lag between recognizing the need for action and measure implementation based on the prognosis of future economic conditions. The presence of change lag of political variables is burdened by the risk of the nature of the problem, which caused the change in political actions, being completely altered during the application of policies [Cooper et al., 1983, 540].

Monetary policy produces effects to economic motions in the situation of portfolio imbalance (real and financial property) of the transactor, which effects the purchase and sale of financial and real assets to restore balance, when the marginal unit of each asset will reject equal income, or when there will be no advantage of changing the possession of different forms of assets.

Further study of the lag phenomenon imposes two questions: what is implied by lag during monetary processes and why are the asset holders unable to immediately adjust their portfolios in the conditions of imbalance?

It is a fact that the transactors do not immediately adjust to altered circumstances for two reasons: (1) they need time to become aware of the conditions and (2) when they become aware of the imbalance in their portfolios, they need time to correct them [Crockett, 1979, 7475]. 
Therefore one of the main insecurities in the application of monetary policies is the lag between the precise need for action and the effect of that action to the ultimate goals of monetary or macroeconomic policy.

The time frame for political action depends on the fundamental stability or instability of the economy. If the inner strength of a stable economy is powerful, short term behavioral changes in the economy can swiftly immobilize autonomous powers to restore balance (McCarty, 1982, 436). This is the reason why the economy can absorb initial changes without any political changes, while political interventions would even be harmful at this point. In case the inner strengths for stability are weak, the required time for autonomous adjustment will be unacceptably long. Political interventions must be passed quickly so the process of stabilizing the economy is as short as possible.

When the information is gathered slowly and is incomplete, it is difficult to come to a swift political decision. Short term goal values can be wide-ranged when compared to fundamental economic conditions. A lag of the effects of political actions causes problems in determining clear goals for immediate action [Živković \& Kožetinac, 2008, 315-316].

\section{COMPONENTS OF LAG}

In time lag analysis, we can differentiate between several of its components [Živković, 1993, 76-79]: (1) Implementation lag which represents the time interval between the moment when monetary actions need to be applied and the moment when the action is implemented and (2) operation lag which is the time interval between the moment of implementation of the instruments of monetary policies and the moment when their effects become apparent on the ultimate goals.

Other such divisions can also be found in economic literature. Inside lag encompasses the following:

- $\quad$ Recognition lag - the time span between the moment when the need for implementation of monetary policies arises and the moment when the monetary authorities act [Živković \& Kožetinac, 2008, 318]. For instance, before any action is undertaken, the existence of any problem has to be identified. The identification of a problem implies gathering and analyzing economic data. Data concerning unemployment and inflation is usually available for the previous month. Let us presume that the unemployment rate for January is available in February. The GDP data is collected quarterly and is accompanied by a long delay. The GDP data for January, February and March, for instance, are available in April or even May. When the data is collected, it is necessary to analyze it and determine with certainty the outcomes of the problems. This analysis often requires data gathered over several months to establish the trends and eliminate temporary statistical digressions.

- Action lag - is the lag between the moment when the monetary authorities act and the moment when the banking system faces altered conditions.

- $\quad$ Outside lag - is the time span between the moment when the banking system functions under altered conditions and the moment when the companies and households, i.e. the non-banking sector, face altered monetary mass and credits [Živković \& Kožetinac, 2008, 318].

If we presume that the time span between the moment when the need for implementation of monetary action arose and the actual implementation of monetary measures is close to zero, then the inside lag is the result of recognition lag [Kraken \& Slow, 1963, 3-7]. 
Wrighstman (1971) differentiates the following forms of lag of effects of monetary politics: (a) first time lag between the need for action and the implementation of monetary action; (b) second time lag between the implementation of monetary action and the effects of the actions to changes in the financial sphere (altered interest rates, monetary mass and other financial variables), or within the real sphere (changes in actual income, production, etc.).

Crockett (1979) believes it is important to differentiate the various kinds of lag based on the moment when the political changes become necessary and the moment when political actions give results. He distinguishes: (a) information lag which is the time needed for gathering the information and presenting it to the policy makers, and which point to future changes in the political course; (b) implementation lag is the time needed to formulate the appropriate policies in terms of the new conditions, and which lasts from the moment the policy makers become aware of the changed circumstances; (c) instrument response lag appears when the immediate variables do not respond to the changes in the instrument variables; and (d) reaction lag representing the lag which includes the reaction of target variables to the change of immediate variables.

Struthers and Speight (1986) came to the following conclusions in their research: the total lag consists of several distinct sections, which can be classified within inside and outside lag. The inside lag can be further split into recognition lag (the time needed to decide which action to implement). The largest portion of this lag is the information lag which arises from the following reasons: (a) information which the economic policy and especially monetary policy makers require to make an accurate picture of the state of the economy, is statistical in nature and needs time (at least a month, and in some cases a quarter or longer) to be gathered and processed. From this it can be concluded that the policy makers always deal with outdated and incomplete information, which can have serious repercussions, depending on whether the situation is changing and how fast; (b) all the variables which are mutually conditioned on the same change tracks cannot be encompassed statistically; (c) some of the short term changes in track movements of a certain variable can statistically point to a new trend in the movement of the observed phenomenon, even though there is a reversible deviation from that trend.

The next inside lag is the implementation lag or administrative lag. It consists of decision lag which is the time needed to establish what is to be done, and action lag which represents the time needed for the decided action to be taken.

Outside lag is the period between the application of political measures and the effects of these changes on the ultimate outcomes of economic policy. Different financial lags should also be mentioned here: interest rate lag for changes in the amount of money; time for the banks and other financial institutions to adjust their portfolios; transactor's reaction lag dealing with money or exacting credits caused by changes in the interest rate; response lag of the new securities on financial markets to changes of interest rates and the general economic climate.

Pierce (1984) states three causes of lag in political actions, and these are: (1) recognition lag; (2) implementation lag; and (3) response lag of the economy to political changes. These three types of lag determine the total duration between the need for a change in the political course and the ultimate effects on the national economy, with the duration of the lag significantly decreasing the ability of monetary politics to stabilize the economy in a short time [Živković \& Kožetinac, 2008, 318-320]. 
Diagram 1. Time lag of the measures of monetary politics

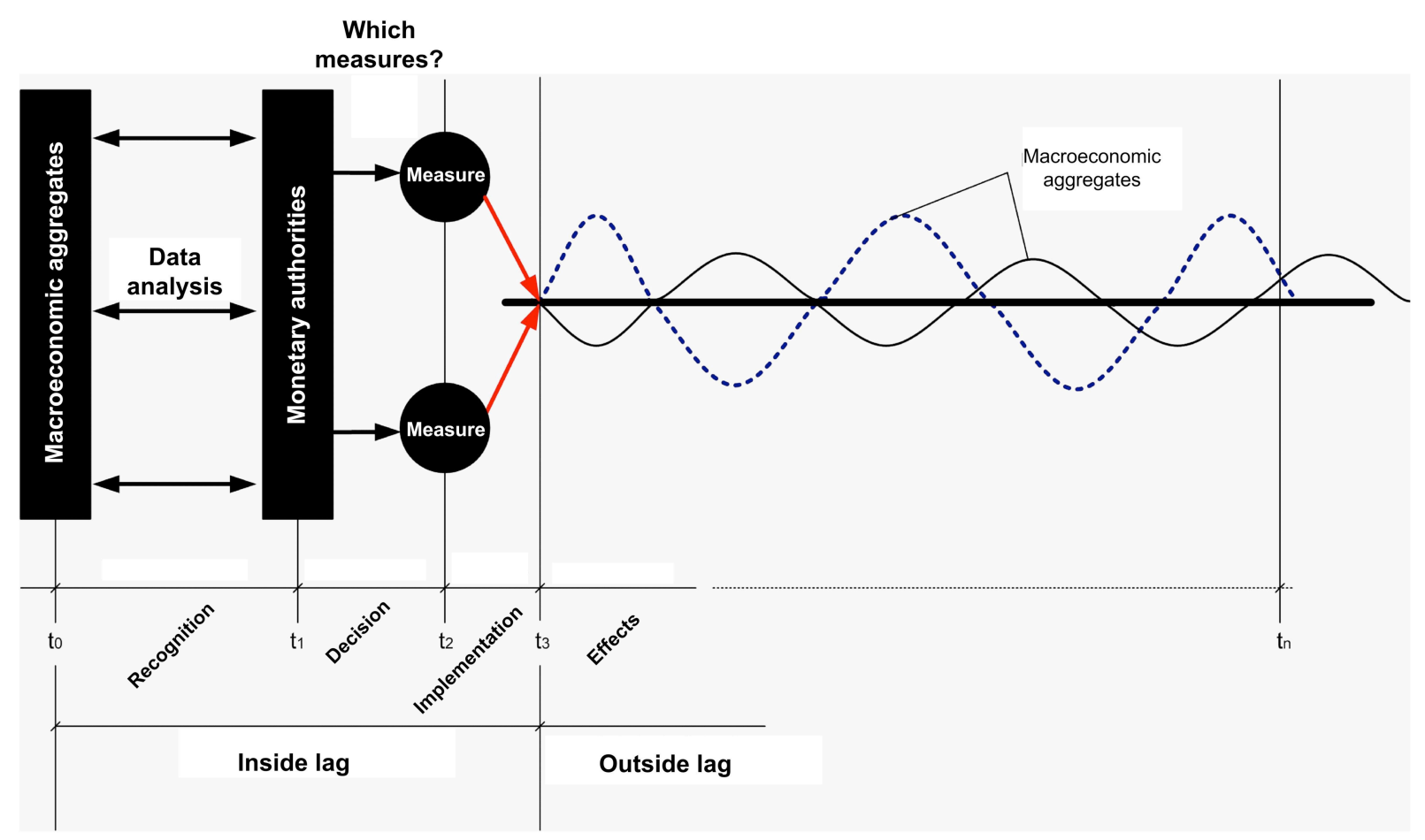

Source: The authors

Empirical evidence in developed market economies shows that the effects of fiscal policy are felt sooner than the effects of monetary policy. Fiscal policy directly influences aggregate demand and income. Monetary policy influences aggregate demand and financial income indirectly, through changes in interest rates and wealth. Fiscal policy is also changed relatively rarely, but its changes seem permanent to the economy subjects. Monetary policy is changed more frequently and the economy transactors find it hard to differentiate between transitory and permanent changes. In addition, the measures of fiscal policies affect aggregate demand sooner, where the shorter effect lag of fiscal policy is not the result of the longer implementation lag of the measures of fiscal politics.

Fiscal and monetary politics are similar in the way of recognition lag; however, while monetary politics have a shorter implementation lag, fiscal policy has a shorter effect lag. Coming to a decision on the plan of monetary politics is faster than that is the case with fiscal politics, which has a longer coordination lag and takes longer to pass the necessary laws. Due to these characteristics, monetary politics is the key instrument of macroeconomic politics in implementation of economic stability [Živković \& Kožetinac, 2008, 321-322]. 
Diagram 2. Time lag of monetary politics and the cyclic movement of economic activity

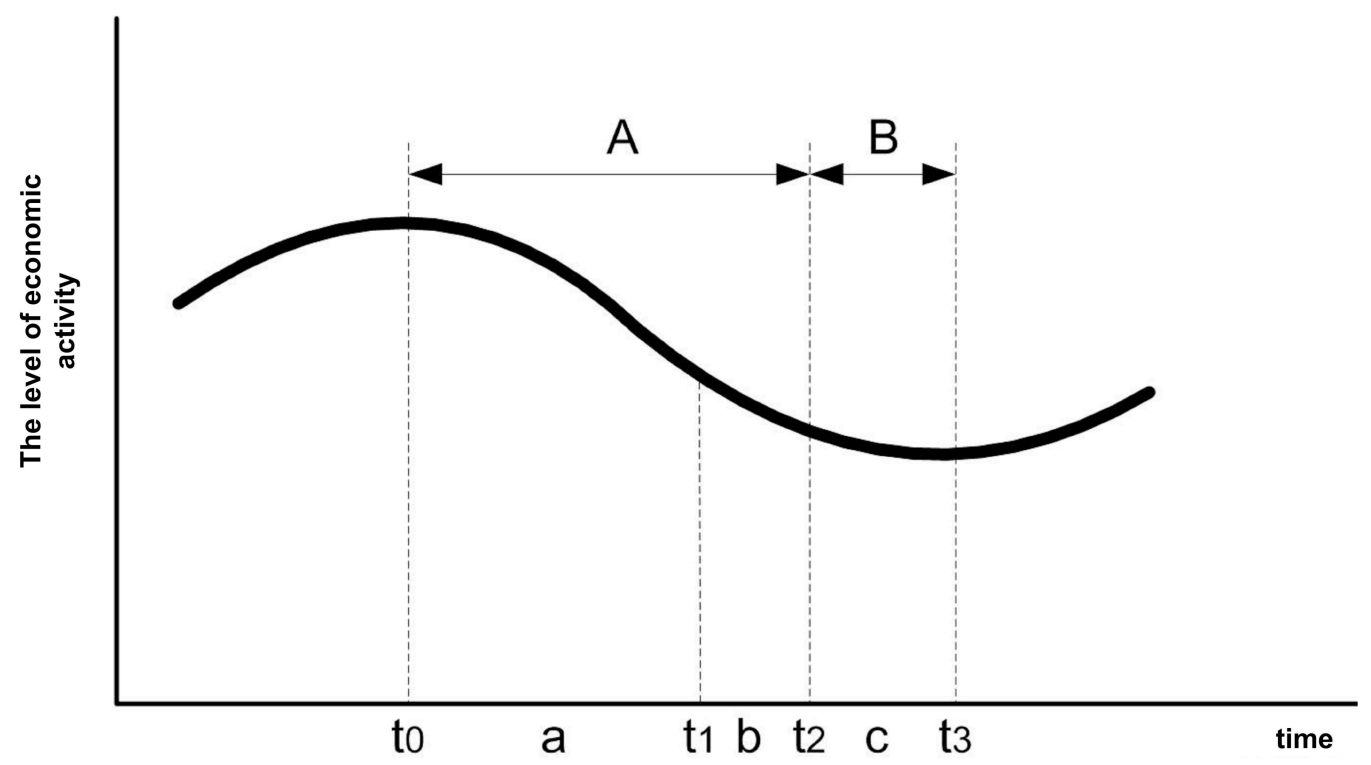

NOTICE: $\quad A=$ Inside lag

a) Recognition lag

$B=$ Outside lag

b) Administration lag

c) Operation lag

Source: [Poindexter \& Jones, 1980, 496-501]

Three phases of lag can be seen on the curve of the business cycle shown in diagram 2. [ Poindexter \& Jones, 1980, 496-501], and these are the following:

- Recognition lag ( $\mathrm{t} 0$ - $\mathrm{t} 1)$ can amount to several months before the stabilization politics bearers become aware of the need for action;

- $\quad$ Administration lag $(\mathrm{t} 1-\mathrm{t} 2)$ shows the interval between recognizing the need for political action and the moment in time when action is taken;

- Operation lag $(\mathrm{t} 2-\mathrm{t} 3)$ is the time interval during which the effects of implemented political measures become evident.

What needs to be stressed is that the main effect on economic activity becomes apparent during time interval $\mathrm{t} 3$. It is because of this that the outside lag is more important than the inside lag, because it shows the postponed effects of implemented monetary policies. Empirical research does not provide solid evidence for the length of this kind of lag and ranges anywhere between a month and up to two or three years, when the actions of monetary politics begin to significantly affect the economy [Živković \& Kožetinac, 2008, 322].

\section{MEASURING THE LENGTH OF MONETARY POLICY MEASURES LAG}

The problem of lag is much more complex than it would seem based on the aforementioned descriptions of this economic phenomenon. The process of lag is manifested in the following way: the reaction to some of the monetary variables is spread during the period of implementation and the effects of political action can accumulate and reach a peak of maximum value sooner or later during the process; they can manifest in the form of amplitudes with several different values. 
The lag in monetary politics comes from two different kinds of problem: the first, if the lag lasts very long - for two or three years - expansive monetary politics can have consequences, maybe even the main consequences to the economic trends in the time when the situation is completely changed and when the restrictions of demand and deceleration of monetary growth become necessary, and vice versa. The second problem is if the lag is unstable and constant, the inclusion of the time factor can become overly difficult, and the effects of that action are slightly better than simple guessing [Struthers \& Speight, 1980, 311313].

Establishing the needed time span to achieve the greatest or complete effect, or producing a given percentage of the complete effect should be included in the terms of measuring the lag of the manifestation of certain monetary variables or measurements.

Postponing the reactions can vary from one immediate variable to another, from one ultimate goal to another. This is the case, for instance, when the short term interest rates are more flexible than long term interest rates, and banking rates being more flexible than interbanking rates. The response lag of some transactors varies in length depending on different activities. Finally, the length of lag varies with respect to the way of formulating the monetary policies and the choice of monetary variables. This is the case in the USA, where the length of the lag depends on the choice of operative monetary variables. While the total bank reserves, the primary money of monetary mass have short term lag of four to five quarters, the unborrowed reserves manifest fully only after a lag of two and a half years [Struthers \& Speight, 1980, 312].

The most important question connected to the implementation of monetary policies is the length of lag. Even though a great deal of empirical research on this subject has been carried out, it is extremely difficult to precisely determine the length of the inside and outside lag above all because that length is variable.

For monetary politics, the insides lag amounts to an average of three to six months (three to four months for recognition and a month to two for action). While the inside lag is longer and highly variable for fiscal policies, the outside lag for monetary policies amounts to anywhere between twelve to eighteen months, and only a few months for fiscal policy. [Willes, 1968, 67-73].

Table 1. The estimated ranking of average time lags for monetary and fiscal policies (in months)

\begin{tabular}{|c|c|c|c|c|}
\hline \multirow{2}{*}{ Policy } & \multicolumn{2}{|c|}{ Inside lag } & \multirow{2}{*}{ Outside lag } & \multirow{2}{*}{ TOTAL lag } \\
\hline & Recognition lag & Action lag & & \\
\hline Monetary policy & 3 & 0 & $1-20$ & $4-23$ \\
\hline Fiscal policy & 3 & $1-15$ & $1-3$ & $5-21$ \\
\hline
\end{tabular}

Source: [Willes, 1968] 


\section{EMPIRICAL EVIDENCE OF TIME LAG}

Although the concept of lag of monetary policies has deep historical roots in the literature of monetary economy, there are only a small number of studies which are focused on studying this economic phenomenon. In their earlier studies, Cagan and Gandolfi (1969) used a time sample of monetary effects on the interest rates as an indirect measure for the trends of expenses and incomes. Their findings indicate that the effect of lag on the actions of monetary policies on incomes sums up to between six months and two years. Friedman (1972), continuing one of his previous works and using the data from the USA and UK, published empirical evidence of the lag of actions of monetary policies (the amount of money, for instance) and its result in the way of inflation, and by doing so confirming his hypothesis from the past. Tanner (1979) tested the variability of lag between the actions of monetary policies and the results in the change of production. His results showed that the length of lag is highly variable. Duduay (1994), using the data from Canada, estimated that the lag of monetary policies with respect to production amounts to twelve to eighteen months and that the lag connected to inflation is from eighteen to twenty-four months. Batini and Nelson (2001) confirm Friedman's (1972) empirical results. Applying the data from the USA and UK from the period from 1953 to 2001, they established that the length of lag of the effects of measures of monetary politics sums up to twenty-five months for the USA and thirteen months for the UK. They also estimated the length of lag by utilizing various samples from this period and they found little proof that the length of lag shortened in the recent years, which led them to the contrary conclusion that the length of lag became longer in the recent period. Hafer et al. (2007) re-examined the role of money and established a statistically strong relationship between lag in the change of the amount of money and the production gap.

From this empirical evidence, the phenomenon of lag in monetary policy becomes obvious, both in the past and the present and remains one of the key factors influencing the management of monetary policy [Nishiyama, 2009, 2].

Due to the variability of the calculated time lag, the importance of the question of efficiency of operations of macroeconomy is growing, and especially in its concept of monetary policy. In the conditions where the length of lag and/or the length susceptible to change, i.e. the variable size, cannot be precisely determined, it is increasingly difficult to manage an efficient stabilization policy. The time needed for monetary policy to influence the key macroeconomic variables is of crucial importance for its benefits as an instrument of macroeconomic stabilization. If the lag of monetary policy is simultaneous and of long and variable duration, the discretional politics can act towards destabilization. [Cooper et al., 1983, 390-391].

In case the total lag lasts longer than the validity period of reliable economic prognosis of target variables, the fulfillment of political goals can have a destabilizing effect. Similarly, the high variability of lag limits the range of monetary policy [Uselton, 1974, 11].

Efficient monetary policy or stabilization policy must be formulated based on reliable economic predictions. The key importance is given to recognition lag rather than prognosis. If the time horizon of reliable economic prognosis is longer than the total lag of the effects of monetary politics, then the only thing that can jeopardize the results of the preferred monetary policy is the unpredictability of the lag [Živković \& Kožetinac, 2008, 327].

\section{CONCLUSION}

The phenomenon of lag in the implementation of measures of monetary politics is a controversial and cumbersome problem of monetary politics because the stabilizing or even destabilizing effect of these measures depends on the length of the lag. Research has shown 
that if the average lag is extremely long and highly variable at the same time, monetary politics can destabilize the situation. Monetary policies must respond eventually, because it takes time for them to become active and begin to affect the economy trends. For successful monetary policy management, it is not enough only to know the length of the lag but also the lasting of the effects of the undertaken monetary actions. In the case of monetary policies, it is essential to possess the right prognosis beforehand to ensure the precise timing and direction of monetary actions. However, when the lag varies, it is difficult to reach a decision in the right direction of the actions, which could lead to contributing to the instability of the economy, if the decisions were made using incomplete and improper information. When discussing this problem, Friedman stated at one point that the empirical evidence persuaded him that it is much more important to prevent monetary changes to contribute to the instability, than it is their exact use to neutralize the other forces at work.

Due to the existence of time lag in the implementation of monetary policy it is not realistic to expect the monetary policies to generate immediate on-line effects. Time needs to pass until the economic transactors adjust to the newly created circumstances and financial conditions, or until the real expenses adjust to the existing amount of money in the monetary system. This must be taken into account while planning and implementing monetary policies, because their efficiency will be greater in the measures which are capable of predicting the future trends ex ante, and with high likelihood, so that the activated instruments of monetary politics in the previous period are appropriate for the upcoming conditions.

\section{LITERATURE}

1. Batini, N., Nelson, E. (2001) "The lag from monetary policy actions to inflation: Friedman revisited", International Finance, 4(3): 381 - 400.

2. Cagan, P., Gandolfi, A. (1969) "The Lag in Monetary Policy As Implied by the Time Pattern of Monetary Effects on Interest Rates", American Economic Review, 59: 277 - 284.

3. Cooper et al. (1983) Money, the Financial System and Economic Policy, Addison-Weseley Publishing Company.

4. Crockett, A. (1979) Money - Theory, Policy and Institutions, Second Edition, Nelson.

5. Duguay, P. (1994) "Empirical Evidence on the Strength of the Monetary Transmission Mechanism in Canada - An aggregate approach.", Journal of Monetary Economics, 33: 39 - 61.

6. Friedman, M. (1972) "Have monetary policy failed?" American Economic Review, 62: 11 - 18.

7. Friedman, M. (1973) Teorija novca i monetarna politika, (Beograd: Rad).

8. Hafer, R.W., Haslag, J.H., Jones, G. (2007) "On money and output: Is money redundant?” Journal of Monetary Economics, 54: 945 - 954.

9. Kraken, I., Slow, R., (1963) Summary of Part I, Lags in Monetary Policy, Stabilization on Policies Commision on Money and Credit (Prentice-Hall).

10. McCarty, M., H. (1982) Money and Banking - Financial Institutions and Economic Policy, (Addison - Wesley Publishing Company ).

11. Nishiyama, S. (2009) Monetary Policy Lag, Zero Lower Bound and Inflation Targeting, (Bank of Canada).

12. Pierce, J., L. (1984) Monetary and Financial Economics, (John Wiley and Sons).

13. Poindexter, J., C. \& Jones, C., P. (1980) Money, Financial Markets and the Economy, (West Publishing Company). 
14. Struthers, J. \& Speight, H., (1980) Money, Institutions, Theory and Policy, (Longman).

15. Tanner, J.E., (1979) "Are the lags in the effects of monetary policy variable?" Journal of Monetary Economics, 5: 105 - 121.

16. Uselton, G., C. (1974) Lags in the Effects of Monetary Policy, (Marcel Dekker).

17. Willes, M., A. (1968) "Lags in Monetary and Fiscal Policy", FRB of Philadelphia Business Review, : 67 - 73.

18. Wrightsman, D. (1971) An Introduction to Monetary Theory and Policy, (New York: The Free Press).

19. Živković, A., \& Kožetinac, G. (2008) Monetarna ekonomija, (Beograd: Centar za izdavačku delatnost Ekonomskog fakulteta).

20. Živković, A., (1993) Analiza efikasnosti monetarne politike u Jugoslaviji, (Beograd: Ekonomski fakultet).

\section{FENOMEN VREMENSKOG POMAKA („LAG“) U PRIMJENI MJERA MONETARNE POLITIKE}

\section{SAŽETAK}

Ovaj rad se bavi teorijskim aspektom fenomena vremenskog kašnjenja u djelovanju mjera monetarne politike. Monetarna i fiskalna politika suočavaju se s fenomenom kašnjenja. Jedno od kontroverznih i opterećujućih pitanja monetarne politike jest priroda $i$ duljina kašnjenja između izvršenja monetarnih mjera i efekata na makroekonomske agregate. Dok monetarna strategija ukazuje na nekoliko mogućih razloga kašnjenja ne postoji opća suglasnost u vezi duljine kašnjenja. Proučavanje fenomena kašnjenja nameće dva pitanja: šta implicira kašnjenje u odvijanju monetarnih procesa $i$ monetarne politike $i$ zbog čega u uvjetima neravnoteže vlasnici aktiva nisu sposobni prilagoditi svoje portfolije neposredno? U ekonomskoj literaturi poznate su dvije kategorije kašnjenja: unutarnje kašnjenje (koje obuhvaća prepoznavanje problema i provedbu mjera) $i$ vanjsko kašnjenje (koje obuhvaća reakciju makroekonomskih agregata na provedene mjere monetarne politike). U radu su deskriptivno navedene različite identifikacije vremenskog kašnjenja a dati su i shematski prikazi djelovanja promatranog fenomena.

Ključne riječi: monetarna politika, mjere monetarne politike, vremensko kašnjenje, problemi kašnjenja, posljedice 